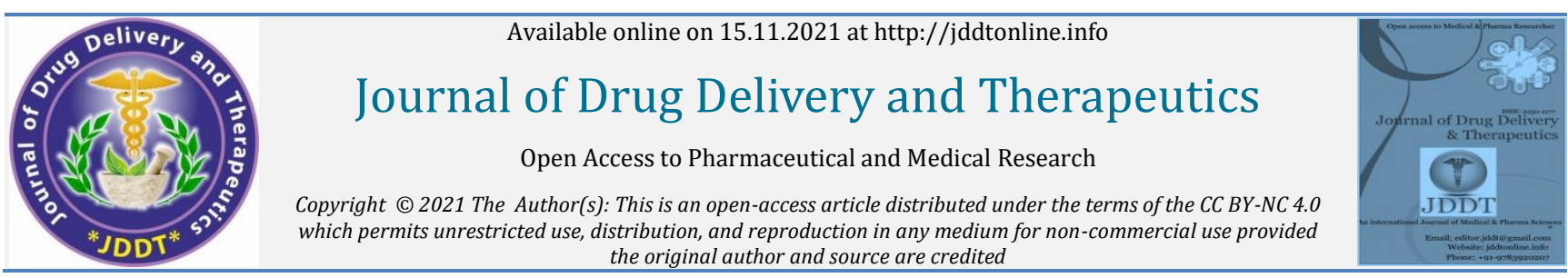
the original author and source are credited

Research Article

Open

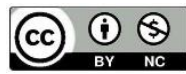

\title{
Therapeutic properties of aqueous extracts of leaves and stems bark of Prosopis africana (Guill. \& Perr.) Taub. (Fabaceae) used in the management of dental caries
}

Bance Alimata ${ }^{1,2 *}$, Sourabié Seydou², Compaoré Souleymane ${ }^{2,3}$, Compaoré Eli , Belem-Kabre W. Leila Marie Esther², Ouedraogo Vincent ${ }^{1}$, Rouamba Ablassé ${ }^{1}$, Ouedraogo Noufou ${ }^{2}$, and Kiendrebeogo Martin ${ }^{1}$

1. Laboratory of Applied Biochemistry and Chemistry (LA.BIO.C.A), University Joseph KI-ZERBO,03 P.O. Box 7021, Ouagadougou 03, Burkina Faso.

2. Department of Traditional Medicine and Pharmacopoeia (MEPHATRA-PH), Institute for Research in Health Sciences (IRSS/CNRST), 03 P.O. Box 7034, Ouagadougou 03, Burkina Faso.

3. Laboratory of Plant Biology and Ecology (LABEV), University Joseph KI-ZERBO, Burkina Faso.

\section{Article Info:

 \\ Article History: \\ Received 14 September 2021 Reviewed 26 October 2021 Accepted 01 November 2021 \\ Published 15 November 2021}

\section{Cite this article as:}

Bance A, Sourabié S, Compaoré S, Compaoré $\mathrm{E}$ Belem-Kabre WLME, Ouedraogo V, Rouamba A Ouedraogo N, Kiendrebeogo $M$, Therapeutic properties of aqueous extracts of leaves and stems bark of Prosopis africana (Guill. \& Perr.) Taub. (Fabaceae) used in the management of dental caries, Journal of Drug Delivery and Therapeutics. 2021; 11(6):108-114

DOI: http://dx.doi.org/10.22270/jddt.v11i6.5152

\section{*Address for Correspondence:}

Bance Alimata, Laboratory of Applied Biochemistry and Chemistry (LA.BIO.C.A), University Joseph KIZERBO,03 P.O. Box 7021, Ouagadougou 03, Burkina Faso.

\section{Abstract}

Prosopis africana (Guill. \& Perr.) Taub. (Fabaceae) is used in the herbal medicine of Burkina Faso to treat dental caries. This study aims to contribute to the valorization of the said plant by investigating the antioxidant, anti-inflammatory and antibacterial properties of aqueous leaves and stems extracts.

The inhibitory activity on lipoxygenase was used to evaluate the anti-inflammatory effect of the extracts. The antioxidant activity of bots extracts of the plant was assessed using DPPH radical scavenging, ABTS+ radical cation decolorization. The anti-biofilm effect of the extracts was evaluated on Streptococcus mutans ATCC 25175, Staphylococcus aureus ATCC 43300, Pseudomonas aeruginosa PAOI and the anti-Quorum sensing effect on Chromobacterium CV026.

Aqueous extracts of Prosopis africana stems show the highest content of phenolic compounds $(30,04 \pm 0,59 \mathrm{mgAGE} / 100 \mathrm{mg}$ extract) while those of the leaves show the highest content of total flavonoids $(3.29 \pm 0.53 \mathrm{mgQE} / 100 \mathrm{mg}$ extract $)$. The aqueous extract of stem bark show the strongest antioxidant activity ( $\mathrm{IC}_{50}=4.58 \pm 0.07 \mu \mathrm{g} / \mathrm{ml}$ for the ABTS) , a best Inhibitory action on activity of lipoxygenase (IC50 = 13.42 $\pm 1.26 \mu \mathrm{g} / \mathrm{mL}$ ), a highest anti-biofilm activity ( $63.6 \%$; at the concentration of $100 \mu \mathrm{g} / \mathrm{ml}$ ) without affecting the bacterial growth. In addition, this extract has the strongest anti-quorum sensing activity with an percentage of inhibition $53,5 \%$.

These findings suggested that the aqueous extracts of stem bark and leaves of Prosopis africana contain promoted phytomolecules to combat dental caries infections.

Keywords : Anti-biofilm, Anti-quorum sensing, Lipoxygenase, Prosopis africana

\section{INTRODUCTION}

Despite the advances in public policies so far, dental caries remains the most prevalent and costly oral infectious disease worldwide 1 , representing a global public health problem to be managed by authorities and dental professionals 2,3 Effective caries-preventive methods have been developed and amended in the last decades. It is well known that the chemical control of plaque is an effective strategy to prevent dental caries development 4 . The main chemical agents currently available are fluoride 5 , chlorhexidine 6 , triclosan, cetylpyridinium chloride, and natural products 4,6 . However, like most antimicrobials, these drugs suffer from resistance phenomena towards cariogenic bacteria due to their union in biofilm 7 . Still, their regular use can also cause other inconveniences such as vomiting, tooth discoloration, and oral cancer 8,9. Also, the problem of timely accessibility of these drugs in all places for the poorest segments of the population, the lack of access to health services is a painful reality 10,11 .

Consequently, the association of traditional medicine with this struggle constitutes a less expensive and more accessible community alternative, provided that the therapeutic effectiveness and safety of the plants used are scientifically proven. Hence, scientists are shifting their attention to folk medicine to find new leads for better against microbial infections. Plant materials are known as a source of new antimicrobial agents; as a result, a search has been made to discover new antibacterial drugs of plant origin 12 .

Numerous medicinal plant extracts or phytochemicals have been shown to inhibit the formation of dental biofilms by reducing the adhesion of microbial pathogens to the tooth surface, a primary event in the initiation and the progression to dental decay13,14. 
Prosopis africana (Guill. \& Perr.) Taub (Fabaceae) is a plant used in traditional medicine for the treatment of oral diseases. An ethnobotanical survey conducted by 15 reported using the plant leaves and stems in rural areas to treat dental caries and the bark in treating green diarrhea in infants. Its antibacterial activity against several strains such as Escherichia coli, Staphylococcus aureus, Streptococcus mutans, Klebsiella pneumonia, Pseudomonas aeruginosa has also been reported 15,16. However, the literature has little investigated the anti-biofilm anti quorum sensing properties of leaves and stem bark extracts. This study investigated the antioxidant, anti-inflammatory, and anti-biofilm activity of the aqueous leaves and stem bark extracts of Prosopis africana.

\section{MATERIALS AND METHODS}

\section{Chemicals}

All chemicals used were analytical grade.FCR 2N (Folinciocalteu reagent); $\mathrm{AlCl} 3$ (aluminium trichloride $(75 \mathrm{~L}, 2 \%$ in methanol)) Prolabo (Paris,France); ABTS (2, 2'-azinobis- [3ethylbenzothiazoline-6-sulfonic acid]) Sigma (Steinheim, Germany); DPPH (2, 2-diphényl-1-picrylhydrazyl) Sigma (Steinheim, Germany); potassium persulfate $\left(\mathrm{K}_{2} \mathrm{~S}_{2} \mathrm{O}_{8}\right)$ (Fluke, France), Trolox (Fluke, France), Zileuton, lipoxygenase (type I-B) Sigma ${ }^{\circledR}$ (St Louis, USA,); boric acid; linoleic acid; quercetin Sigma (Steinheim, Germany); gallic acid Sigma (Steinheim, Germany).

\section{Bacterial Strains}

Streptococcus mutans ATCC 25175 and Staphylococcus aureus ATCC 43300 (methicillin-resistant) strains were provided by the bacteriology laboratory of the Muraz Center in Bobo Dioulasso and the wild type Pseudomonas aeruginosa PAO1 and Chromobacterium violaceum CV026 strain by the plant biotechnology laboratory (L.B.V.) of the Université Libre de Bruxelles (Belgium). All strains were stored at $80^{\circ} \mathrm{C}$ in B.H.I. (Brain Heart Infusion) liquid medium for Staphylococcus aureus and Streptococcus mutans; and L.B. (Luria-Bertani) for Pseudomonas aeruginosa, Chromobacterium violaceum CV026 supplemented with 50\% glycerol until use.

\section{Plant material and extraction}

P. africana stem bark and leaves were collected from the province of Zounweogo under traditional healer assistance. The plant material was taxonomically identified under the voucher $\mathrm{N}^{\circ} 6852$ by a botanist, and a specimen was deposited at the herbarium of University Joseph KI-ZERBO. The fresh material collected was dried in a greenhouse with air circulation and then powdered until use.

For the extraction, one hundred grams (100 g) of leaf and stem bark powders of Prosopis africana (Guill. \&Perr.) Taub obtained are boiled in $1000 \mathrm{~mL}$ distilled water for $30 \mathrm{~min}$. After cooling, the extract was first filtered through a nylon cloth and then cotton. The filtrates thus obtained were immediately concentrated in the oven after centrifugation at $2000 \mathrm{rpm}$ for $5 \mathrm{~min}$. The obtained supernatant was recovered and concentrated, then lyophilized and recovered in white hermetically sealed vials and stored at $+4^{\circ} \mathrm{C}$ until use.

\section{Total polyphenol and Flavonoid Content determination}

Total polyphenol was determined according to the colorimetric method of Folin-Ciocalteu 17.

Plant extract (25 L, $100 \mathrm{~g} / \mathrm{mL}$ in methanol) was mixed with Folin-Ciocalteu Reagent (125 L, $0.2 \mathrm{~N}$ ) and, 5 min later, with sodium bicarbonate $(100 \mathrm{~L}, 75 \mathrm{~g} / \mathrm{L})$. After incubation $(1 \mathrm{~h}$, room temperature), absorbance was measured at $760 \mathrm{~nm}$ against a methanol blank. Gallic acid (0-100 mg/L) was used to generate a standard calibration curve $(\mathrm{Y}=0.005 \mathrm{X}+$ 0.00968; R2 = 0.99), and total phenolic content was expressed as mg gallic acid equivalent to $100 \mathrm{mg}$ of plant extract (mg GAE/100 mg).Total flavonoid was estimated according to the Dowd method 17 . Plant extract $(75$ L,100 $\mathrm{g} / \mathrm{mL}$ in methanol) was mixed with aluminum trichloride $(75$ L, $2 \%$ in methanol). Absorbance was subsequently read at $415 \mathrm{~nm}$ after incubation (10 min, room temperature) against a methanol blank. Quercetin $(0-100 \mathrm{mg} / \mathrm{L})$ was used to plot a standard calibration curve $(\mathrm{Y}=0.02891 \mathrm{X}+0.0036$; $\mathrm{R} 2=$ 0.99), and total flavonoid content was expressed as mg of quercetin equivalent to $100 \mathrm{mg}$ of plant extract (mg QE/100 $\mathrm{mg}$ ).

\section{Anti-oxidant Assays}

\section{ABTS (2, 2'-azinobis- [3-ethylbenzothiazoline-6-sulfonic acid]) test}

The capacity of extracts to scavenge the ABTS radical cation was determined according to the procedure described previously ${ }^{18}$. A stock solution of ABTS $(7 \mathrm{~mm})$ was mixed with $2.45 \mathrm{~mL}$ of potassium persulfate $\left(\mathrm{K}_{2} \mathrm{~S}_{2} \mathrm{O}_{8}\right)$. The mixture was stored out of the light at room temperature for $12-16 \mathrm{~h}$ before use. A cascade dilution range of the extracts and Trolox (reference substance) was performed from a $1 \mathrm{mg} / \mathrm{mL}$ concentration to determine the inhibitory concentration at $50 \%$ (IC50). So, $20 \mu \mathrm{L}$ of each dilution was mixed with $200 \mu \mathrm{L}$ of the ABTS solution diluted in ethanol in the 96-wells microplate. The absorbances were read against blank (ethanol) at $734 \mathrm{~nm}$ on a spectrophotometer (Epoch Biotek Instruments, U.S.A.) after $30 \mathrm{~min}$ of incubation in the dark at room temperature. The test was performed in triplicate, and the percentage inhibition was determined by the following formula:

$$
\% \text { Inhibition }=(\mathrm{Ab}-\mathrm{As}) / \mathrm{Ab} \times 100
$$

Ab: Absorbance of blank; AS: Absorbance of sample/reference compound.

\section{DPPH (2, 2-diphényl-1-picrylhydrazyl) test}

DPPH radical scavenging ability of extracts was assayed as described previously ${ }^{19}$. A cascade dilution of the extract and Trolox (reference substance) was performed from a concentration of $1 \mathrm{mg} / \mathrm{mL}$.

For this purpose, $200 \mu \mathrm{L}$ of DPPH solution freshly prepared in methanol $(4 \mathrm{mg} / 100 \mathrm{~mL})$ was mixed with $100 \mu \mathrm{L}$ of each dilution in the 96-wells microplate. The mixture was incubated for $30 \mathrm{~min}$ at ambient temperature, and the absorbances were measured at $517 \mathrm{~nm}$ against a blank (methanol) with a spectrophotometer (Epoch Biotek Instruments, U.S.A.). The DPPH radical inhibition was calculated as follows:

$$
\% \text { Inhibition }=(\mathrm{Ab}-\mathrm{As}) / \mathrm{Ab} X 100 .
$$

Ab: absorbance of blank; As absorbance of sample/reference compound.

\section{Anti-inflammatory activity in vitro}

The inhibitory activity of lipoxygenase was determined according to the spectrophotometric method described by 20 with slight modifications. $146.25 \mu \mathrm{L}$ of lipoxygenase solution $(820.51 \mathrm{U} / \mathrm{ml})$ prepared in boric acid buffer $(0.2 \mathrm{M}, \mathrm{pH} 9.0)$ was mixed with $3.75 \mu \mathrm{L}$ of extracts $(8 \mathrm{mg} / \mathrm{ml})$ in the 96 -wells microplate and then incubated at room temperature for 3 min. The reaction was initiated by adding $150 \mu \mathrm{L}$ of the substrate (1.25 mm of linoleic acid). The absorbances were recorded for $3 \mathrm{~min}$ at $234 \mathrm{~nm}$ with a spectrophotometer (Epoch Biotek Instruments, U.S.A.). All tests were performed in triplicate, and Zileuton was used as a reference compound. 
The inhibitory percentages were calculated using the formula:

$$
\% \text { Inhibition }=(\mathrm{Vb}-\mathrm{Vs}) / \mathrm{Vb} \times 100
$$

Vb: Enzymatic activity without inhibitor; Vs. Sample: Enzymatic activity with sample/reference compound.

\section{Anti-biofilm activity}

The anti-biofilm activity of the extracts was evaluated according to the method described by ${ }^{21}$. Streptococcus mutans ATCC 25175, Staphylococcus aureus ATCC 43300, and Pseudomonas aeruginosa PA01 were used as bacterial strains. The extracts and the reference (salicylic acid) were prepared at the $1 \mathrm{mg} / \mathrm{mL}$ concentration in DMSO (1\%) to have a final concentration in each well of $100 \mu \mathrm{g} / \mathrm{mL}$. After incubating the plates for $24 \mathrm{~h}$ at $37{ }^{\circ} \mathrm{C}$ containing each bacterial strain and extract, bacterial turbidity was measured at $600 \mathrm{~nm}$ to ensure that the extracts did not affect bacterial growth compared to the negative control (1\% DMSO). For the anti-biofilm activity, the supernatant from each well was then removed, and the biofilms were washed with distilled water, fixed with methanol for $15 \mathrm{~min}$, and dried. Crystal violet $0.1 \%$ (in water) was added to each well, and the plates were incubated for $30 \mathrm{~min}$ at room temperature. After removal of the crystal violet, the wells were rinsed with distilled water, and $200 \mu \mathrm{L}$ of acetic acid (33\% in water) was added to dissolve the crystal violet. The absorbances of the solution were read at $590 \mathrm{~nm}$, and the biofilm/bacterial growth ratio (OD $590 \mathrm{~nm} / \mathrm{DO} 600 \mathrm{~nm}$ ) was determined.

\section{Anti-quorum sensing activity}

\section{Inhibition test of violacein production in $C$. violaceum CV026}

C. violaceum was grown for $24 \mathrm{~h}$ at $30^{\circ} \mathrm{C}$ under agitation at $175 \mathrm{rpm}$. CV026 was diluted and introduced into 12 -well plates. Then extracts/reference (salicylic acid) dissolved in DMSO (1\%) were added (final concentration of $100 \mu \mathrm{g} / \mathrm{mL}$ ) in the presence of $10 \mu \mathrm{M}$ of C6-HSL. The plates were incubated for $24 \mathrm{~h}$ at $30^{\circ} \mathrm{C}, 175 \mathrm{rpm}$. Bacterial turbidity (OD $600 \mathrm{~nm}$ ) was measured to assess bacterial growth, and then $1 \mathrm{~mL}$ of each well was collected and introduced into tubes to quantify violacein. The solution was vortexed vigorously for $30 \mathrm{~s}$ to solubilize the violacein, and then the supernatant was removed, and $1 \mathrm{~mL}$ of DMSO was added to the pellet. After centrifugation at $7000 \mathrm{rpm}$ for $10 \mathrm{~min}, 200 \mu \mathrm{L}$ of the supernatant containing violacein was introduced into 96well microplate wells. The violacein production was quantified by measuring the absorbance at $585 \mathrm{~nm}$, and the ratio of OD $585 \mathrm{~nm}$ to OD $600 \mathrm{~nm}$ was also determined.

\section{Statistical analysis}

The experiments were performed in triplicate $(n=3)$, and the results were expressed as mean \pm standard deviation. Graph Pad Prism version 6 software was used for statistical analysis, graphing. The results obtained were expressed as mean \pm Standard Error Mean ( \pm S.E.M.). One-way analysis of variance (ANOVA) followed by Dunnett's test was used to measure the statistical significance of the results.

\section{RESULTS}

\section{Total phenolics and total flavonoid contents}

Table 1 presents the phenolic and total flavonoid contents obtained in the extracts according to the type of plant organ. Indeed, the highest content of phenolic compounds was obtained with the aqueous extracts of stems $(30.04 \pm 0.59$
mgAGE/100 mg extract), and the aqueous extract of leaves show the highest quantity of total flavonoids (mgQE/100mg extract).

Table 1: Total phenolics and flavonoids contents of aqueous extracts of leaves and stem of P. africana

\begin{tabular}{lcc}
\hline Extracts & $\begin{array}{c}\text { Total flavonoids } \\
(\mathrm{mgQE} / 100 \mathrm{mg} \text { extract })\end{array}$ & $\begin{array}{c}\text { Total phenolics } \\
\text { (mgAGE } / 100 \mathrm{mg} \text { extract })\end{array}$ \\
\hline LDE & $3.29 \pm 0.53^{\mathrm{ns}}$ & $14.42 \pm 0.25^{* * * *}$ \\
\hline SDE & $1.03 \pm 2.69^{\mathrm{ns}}$ & $30.04 \pm 0.59^{* * * *}$ \\
\hline Mean values \pm standard deviation were presented $(\mathrm{n}=3)\left({ }^{* * * *}\right)=\mathrm{p}<$ \\
0.0001 is considered significant ; ns: no significance P $>0.05 . ;$ LDE: \\
\multicolumn{2}{l}{ Leaves Decocted Extract; S.D.E.: Stems decocted extract; G.A.E.: } \\
Gallic acid equivalent; Q.E.: quercetin equivalent
\end{tabular}

\section{Antioxidant activity}

Data of the antioxidant activities of extracts through two methods (ABTS, DPPH) are indicated in Table2. Both extracts exhibited good antioxidant activities. The stem bark extract exhibited the best anti- DPPH activity, while the leaves extract showed the best anti- ABTS activity. The anti-DPPH activity of plant extracts was less than the reference compound (Trolox). However, the plant extracts and Trolox showed similar anti-ABTS activity $(\mathrm{p}>0.05)$.

Table 2: Antioxidant activity (ABTS, DPPH) of plant extracts

\begin{tabular}{ccc}
\hline Extracts & $\begin{array}{c}\text { DPPH } \\
\mathrm{IC}_{50}(\mu \mathrm{g} / \mathrm{mL})\end{array}$ & $\begin{array}{c}\text { ABTS } \\
\mathrm{IC}_{50}(\mu \mathrm{g} / \mathrm{mL})\end{array}$ \\
\hline LDE & $20,32 \pm 1,89^{* * * *}$ & $4.58 \pm 0.07^{\mathrm{ns}}$ \\
\hline SDE & $16,39 \pm 0,26^{* * * *}$ & $7.57 \pm 0.04^{\mathrm{ns}}$ \\
\hline Trolox & $7,17 \pm 0,11^{\mathrm{ns}}$ & $3.82 \pm 0.018^{\mathrm{ns}}$ \\
\hline
\end{tabular}

Values are expressed as mean \pm SEM, $n=3\left({ }^{* * * *}\right)=p<0.0001$ is considered significant compared to the control, ns: no significance $P$ $>$ 0.05. Plant extracts vs. Trolox for ABTS, DPPH (one-way ANOVA analysis followed by Dunnett multiple comparisons). LDE: Leaves decocted extract; S.D.E.: Stem decocted extract

\section{Anti-inflammatory activity}

The inhibitory effect of P. africana extracts on lipoxygenase activity is presented in Table 3 below. The aqueous stem bark extract showed the best inhibitory concentration (IC50 $=13.42 \pm 1.26 \mu \mathrm{g} / \mathrm{mL}$ ) compared to the aqueous leaf extract

Table 3 : Lipoxygenase (L.O.X.) inhibitory concentrations (IC50) of extracts

\begin{tabular}{ll}
\hline Extracts & $\begin{array}{c}\text { Anti-lipoxygenase activity } \\
(\mathbf{I C} \mathbf{5 0}) \boldsymbol{\mu g} / \mathbf{m L} \mathbf{)}\end{array}$ \\
\hline LDE & $35.11 \pm 1.05^{* * *}$ \\
\hline SDE & $13.42 \pm 1.26^{* *}$ \\
\hline Zileuton & $4.08 \pm 0.80$ \\
\hline${ }^{* *}$ p $<0.01,^{* * *}<<0.001$, Zileuton vs extracts. LDE: Leaves decocted \\
extract; S.D.E.: Stem decocted extract
\end{tabular}

\section{Anti-biofilm effect of extracts}

As shown in figure 1, the aqueous leaves and stems bark extract at the $100 \mu \mathrm{g} / \mathrm{mL}$ concentration did not affect the bacterial growth of Pseudomonas aeruginosa PA01, Staphylococcus aureus ATCC 43300, Streptococcus mutans ATCC 25175, and Chromobacterium violaceum 026. Nevertheless, compared to DMSO, the extracts significantly reduced the biofilm formation. For all strains, the inhibition of biofilm by the extracts was more significant on Streptococcus mutans ATCC 25175. Plant extracts were more active than the reference compound (salicylic acid) in the Streptococcus mutans biofilm inhibition. 

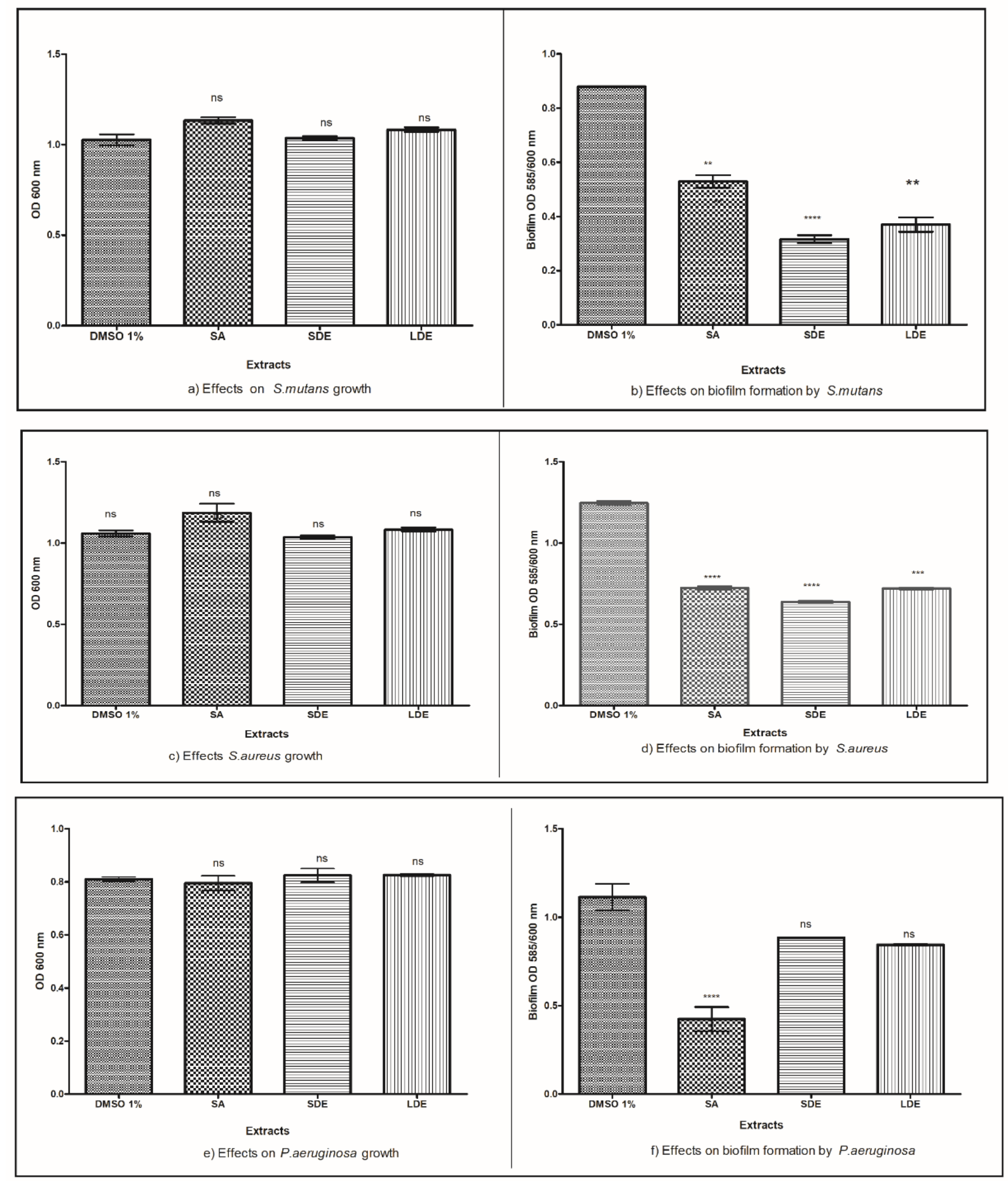

Figure 1: Effect of $P$. africana extracts on biofilm formation of cariogenic bacteria

ns: not significant compared to DMSO control (P< 0.05). SA : Salicylique Acid ; SDE : Stem Decocted extract ; LDE: Leaves Decocted Extract

\section{Effect of extracts on violacein production in Chromobacterium violaceum CV026}

At the final concentration of $100 \mu \mathrm{g} / \mathrm{ml}$, the extracts did not affect the bacterial growth of Chromobacterium violaceum CV026 figure 2a. The C. violaceum CV026 strain, deficient in the homoserine-lactone synthase gene civil, was used to evaluate the ability of the extracts to interfere with the Quorum Sensing mechanism. As shown in figure $2 \mathrm{~b}$, the extracts significantly reduced the production of violacein compared to DMSO. The stem bark extract showed higher anti-quorum sensing activity than the leave extract and the reference compound. 


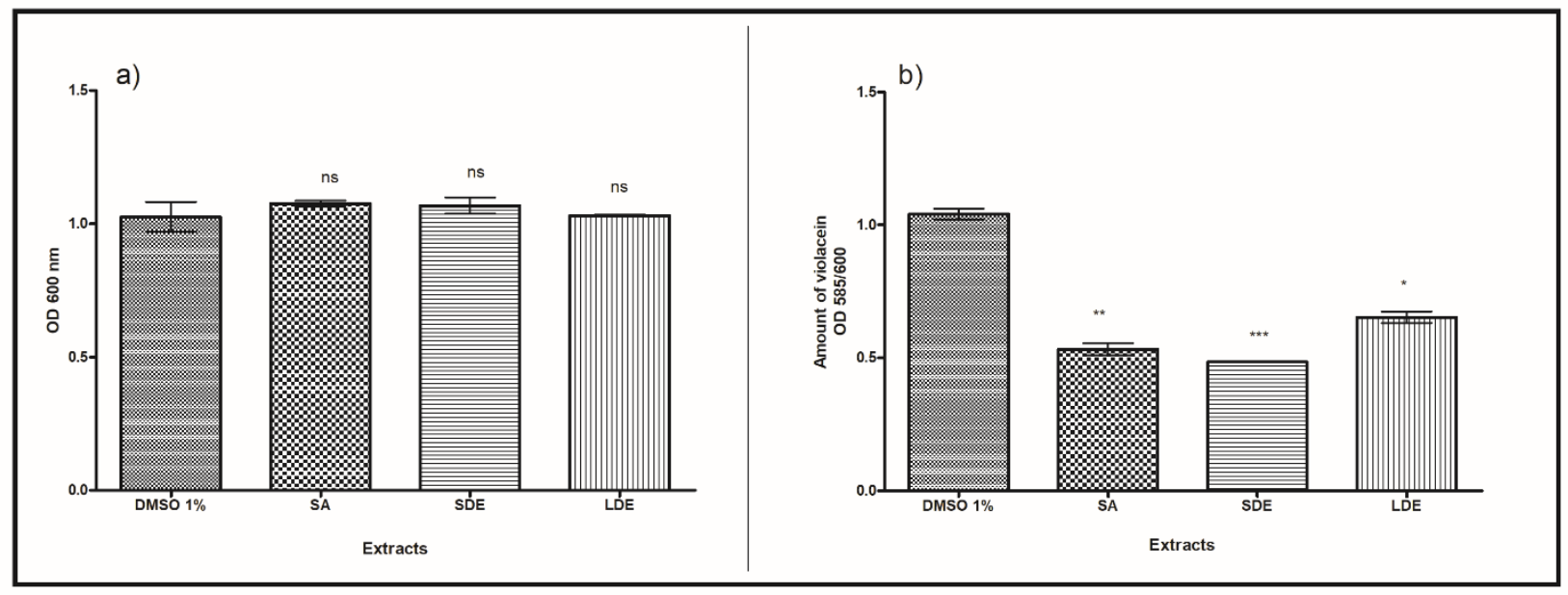

Figure 2: Effect of P. africana extracts on violacein production in C. violaceum CV026

ns: not significant compared with DMSO control $(\mathrm{P}<0.05)^{*}$, $(\mathrm{P}<0.0001)^{* * * *}$ significant difference compared to DMSO.SA : Salicylique Acid ; SDE : Stem decocted extract; LDE: Leaves decocted extract

\section{DISCUSSION}

Prosopis africana is used in traditional medicine to treat microbial infections, particularly bacterial ones. This plant is thus a potential source for the research of new compounds targeting the inhibition of biofilm and the production of virulence factors in a dental infection.

The results of the ABTS antiradical activity show that the $\mathrm{IC}_{50}$ of the leaf and stem extracts of Prosopis africana is comparable to that of the reference substance (Trolox). For DPPH, the best activity was observed by the stem decoctate with an IC 50 . In general, the extracts presented an excellent antioxidant activity. The antioxidant capacity of the extracts of stems bark and leaves would be due to the polyphenols. This activity would be mainly due to their redox properties, which may play an important role in absorbing and neutralizing free radicals ${ }^{16}$. The antioxidant activity of Prosopis africana extracts thus observed is an argument that can justify its traditional use, especially for its antiinflammatory and antibacterial properties. Indeed, the literature has often noted the close link between these properties and the antioxidant potential of the plant, and several authors 22,23 explain the anti dental biofilm effect of many plants by their ability to relieve cells of oxidative stress induced by dental biofilm and quorum sensing. Similarly, it is now recognized that oxidative stress is an essential underlying factor in immune system dysfunction and plays a crucial role in inflammatory processes ${ }^{24-26}$. The oxidative stress caused by dental inflammation could be treated with Prosopis africana extracts.

The lipoxygenase inhibition test allowed us to appreciate a possible anti-inflammatory mode of action of $P$. africana extracts. Indeed, the extracts inhibited the activity of lipoxygenase. The best inhibition was obtained with the stem decoctate (SDE) (IC $50=13.42 \pm 1.26 \mu \mathrm{g} / \mathrm{mL}$ ), the leaf decoctate $(\mathrm{LDE})\left(\mathrm{IC}_{50}=35.11 \pm 1.05 \mu \mathrm{g} / \mathrm{mL}\right)$.

Indeed, the lipoxygenase inhibition would be done by synergizing the actions of phytochemical groups, such as polyphenols that compose the extracts. Polyphenols are known for their inhibitory properties of pro-inflammatory enzymes 27,28. Lipoxygenase (L.O.X.) is an enzyme used in leukotriene biosynthesis 29,30. These leukotrienes play a crucial role in inflammatory diseases such as dental caries, periodontitis, asthma, rheumatoid arthritis, cardiovascular diseases, and cancer. ${ }^{31}$. Inhibiting L.O.X. by the extracts could help decrease the increased release of proinflammatory cytokines (Il-1 $\beta$, Il-6, IL-10, TNF $\alpha$, INF $\gamma$, PGE2...), and several metalloproteinases due to dental inflammation 32 .

Dental biofilm confers antibiotic resistance to cariogenic bacteria 33 . The factor attributed to resistance in dental biofilm is the presence of extracellular polymeric substances (EPS), also known as glycocalyx, that surround the cells and act as a physical barrier that prevents molecules from entering the cells 34,35 .The results obtained from this study reflect an inhibitory effect of $P$. africana leave and stem decocts on the biofilm of $S$. mutans ATCC, $S$. aureus ATCC, $P$. aeruginosa PA01, on the production of violacein, without affecting the bacterial growth. Indeed biofilm inhibition, violacein inhibition is not associated with a bactericidal or bacteriostatic effect but with an interference with the quorum sensing system ${ }^{36}$. Polyphenols and flavonoids are known for their anti-biofilm and anti- Quorum sensing potential 37,38. The anti-biofilm and anti-Quorum sensing activity of Prosopis africana extracts could be due to these compounds quorum sensing and biofilm are, therefore, new targets for the development of new antimicrobial strategies to inhibit the production of virulence factors by pathogenic bacteria $^{39}$. The inhibitory effect of $P$. africana extracts on dental biofilm and virulence factors controlled by quorum sensing could explain its use in traditional medicine against oral diseases ${ }^{14}$.

\section{CONCLUSION}

This study showed that aqueous extracts of Prosopis africana leaves and stem barks are potent sources of anti-biofilm, anti-quorum, anti-inflammatory and anti-oxidant phytomolecules. The results justify the use of Prosopis africana in Burkina Faso herbal medicine by traditional healers to treat dental caries. Further phytochemical studies are needed to characterize the bioactive compounds responsible for these biological properties.

Acknowledgments :The authors thank Mr. YARO Boubacar for the support provided during the laboratory work.

Conflict of Interest : The authors declare that they have no conflicts of interest

Funding : None. 


\section{REFERENCES}

1 OMS. Rapport sur la santé buccodentaire dans le monde.Disponible sur http://whqlibdoc.who.int /hq/2003 /WHO_NMH_NPH_ORH_03.2_fre.pdf. 2003.

2 Bönecker M, Pucca Junior GA, Costa PB, Pitts N. A social movement to reduce caries prevalence in the world. Braz Oral Res 2012; 26:491-492. https://doi.org/10.1590/S180683242012000600001

3 Bagramian RA, Garcia-Godoy F, Volpe AR. The global increase in dental caries. A pending public health crisis. Am J Dent 2009; 22: 3-8.

4 Gunsolley JC. Clinical efficacy of antimicrobial mouthrinses. J Dent 2010; 38: S6. https://doi.org/10.1016/S0300-5712(10)70004$\mathrm{X}$

5 Maguire A. ADA clinical recommendations on topical fluoride for caries prevention. Evid Based Dent 2014; 15:38-39. https://doi.org/10.1038/sj.ebd.6401019

6 Samuels N, Grbic JT, Saffer AJ, Wexler ID, Williams RC. Effect of an herbal mouth rinse in preventing periodontal inflammation in an experimental gingivitis model: a pilot study. Compend Contin Educ Dent 2012; 33.

7 Gomashe A V, Sharma AA and, Kasulkar A. Original Research Article Investigation of Biofilm Inhibition Activity and Antibacterial Activity of Psidium guajava Plant Extracts against Streptococcus mutans Causing Dental Plaque. Int J Curr Microbiol Appl Sci 2014; 3:335-351.

8 Chung JY, Choo JH, Lee MH, Hwang JK. Anticariogenic activity of macelignan isolated from Myristica fragrans (nutmeg) against Streptococcus mutans. Phytomedicine 2006; 13:261-266. https://doi.org/10.1016/j.phymed.2004.04.007

9 Park KM, You JS, Lee HY, Baek NI, Hwang JK. Kuwanon G: An antibacterial agent from the root bark of Morus alba against oral pathogens. J Ethnopharmacol 2003; 84:181-185. https://doi.org/10.1016/S0378-8741(02)00318-5

10 Githiori JB, Höglund J, Waller PJ, Baker RL. Anthelmintic activity of preparations derived from Myrsine africana and Rapanea melanophloeos against the nematode parasite, Haemonchus contortus, of sheep. J Ethnopharmacol 2002; 80:187-191. https://doi.org/10.1016/S0378-8741(02)00030-2

11 Ketzis JK, Taylor A, Bowman DD, Brown DL, Warnick LD, Erb HN. Chenopodium ambrosioides and its essential oil as treatments for Haemonchus contortus and mixed adult-nematode infections in goats. Small Rumin Res 2002; 44:193-200. https://doi.org/10.1016/S0921-4488(02)00047-0

12 Parekh J, Chanda S. In vitro antibacterial activity of the crude methanol extract of Woodfordia fruticosa Kurz. flower (Lythraceae). Brazilian J Microbiol 2007; 38:204-207. https://doi.org/10.1590/S1517-83822007000200004

13 Faron MLB, Perecin MB, Lago AA do, Bovi OA, Maia NB. Temperatura, nitrato de potássio e fotoperíodo na germinação de sementes de Hypericum perforatum L. e H. Brasiliense Choisy. Bragantia 2004; 63:193-199.

https://doi.org/10.1590/S0006-87052004000200004

14 Palombo EA. Traditional medicinal plant extracts and natural products with activity against oral bacteria: Potential application in the prevention and treatment of oral diseases. Evidence-based Complement Altern Med 2011; 2011. doi:10.1093/ecam/nep067. https://doi.org/10.1093/ecam/nep067

15 Alimata B, Dofini MR, Souleymane C, Eli C, Noufou O, Seydou SD et al. The Ethnobotanical Survey, Antibacterial Activity and Phytochemical Screening of Extracts of Prosopis africana (Guill. \& Perr.) Taub. European J Med Plants 2020; 31: 39-47. https://doi.org/10.9734/ejmp/2020/v31i330221

16 Karou SD, Tchacondo T, Micheline AT. Screening Togolese medicinal plants for few pharmacological properties. 2012. doi:10.4103/0974-8490.94737. https://doi.org/10.4103/09748490.94737
17 Lamien-Meda A, Lamien CE, Compaoré MMY, Meda RNT, Kiendrebeogo M, Zeba B et al. Polyphenol content and antioxidant activity of fourteen wild edible fruits from Burkina Faso. Molecules 2008; 13:581-594. https://doi.org/10.3390/molecules13030581

18 Re R, Pellegrini N, Poteggent A P, A, Yang M R-EC. Antioxidant activity applying an improved ABTS radical cation decolorization assay. Free Radical. Biol Med 1999; 26(9/10):1231-1237. https://doi.org/10.1016/S08915849(98)00315-3

19 Velázquez E, Tournier HA M de, Buschiazzo P, Saavedra G SG. Antioxidant activity of Paraguayan plant extracts. Fitoterapia 2003; 74(1-2):91-97. https://doi.org/10.1016/S0367326X(02)00293-9

20 Malterud KE, Rydland KM. Inhibitors of 15-lipoxygenase from orange peel. J Agric Food Chem 2000; 48: 5576-5580. https://doi.org/10.1021/jf000613v

21 Vandeputte OM, Kiendrebeogo M, Rajaonson S, Diallo B, Mol A, Jaziri $\mathrm{M} \mathrm{El}$ et al. Identification of catechin as one of the flavonoids from combretum albiflorum bark extract that reduces the production of quorum-sensing-controlled virulence factors in pseudomonas aeruginosa PAQ1. Appl Environ Microbiol 2010; 76:243-253. https://doi.org/10.1128/AEM.01059-09

22 Lazarini JG, Sardi J de CO, Franchin M, Nani BD, Freires IA, Infante J et al. Bioprospection of Eugenia brasiliensis, a Brazilian native fruit, as a source of anti-inflammatory and antibiofilm compounds. Biomed Pharmacother 2018; 102:132-139. https://doi.org/10.1016/j.biopha.2018.03.034

23 De Marco S, Piccioni M, Pagiotti R, Pietrella D. Antibiofilm and Antioxidant Activity of Propolis and Bud Poplar Resins versus Pseudomonas aeruginosa. Evidence-based Complement Altern Med 2017; 2017. doi:10.1155/2017/5163575. https://doi.org/10.1155/2017/5163575

24 Sordillo LM, Contreras GA, Aitken SL. Metabolic factors affecting the inflammatory response of periparturient dairy cows. Anim Health Res Rev 2009; 10:53-63. https://doi.org/10.1017/S1466252309990016

25 Vajdovich P. Free Radicals and Antioxidants in Inflammatory Processes and Ischemia-Reperfusion Injury. Vet Clin North Am Small Anim Pract 2008; 38:31-123. https://doi.org/10.1016/j.cvsm.2007.11.008

26 Valko M, Leibfritz D, Moncol J, Cronin MTD, Mazur M, Telser J. Free radicals and antioxidants in normal physiological functions and human disease. Int J Biochem Cell Biol 2007; 39:44-84. https://doi.org/10.1016/j.biocel.2006.07.001

27 Karunaweera N, Raju R, Gyengesi E, Munch G. Plant polyphenols as inhibitors of $\mathrm{nf}-\mathrm{Kb}$ induced cytokine production-A potential anti-inflammatory treatment for alzheimer's disease? Front Mol Neurosci 2015; 8:1-5.

https://doi.org/10.3389/fnmol.2015.00024

28 Perera HDSM, Samarasekera JKRR, Handunnetti SM, Weerasena OVDSJ, Weeratunga HD, Jabeen A et al. In vitro proinflammatory enzyme inhibition and antioxidant potential of selected Sri Lankan medicinal plants. BMC Complement Altern Med 2018; 18:1-15. https://doi.org/10.1186/s12906-0182335-1

29 Alestas T, Ganceviciene R, Fimmel S, Müller-Decker K, Zouboulis CC. Enzymes involved in the biosynthesis of leukotriene B 4 and prostaglandin E 2 are active in sebaceous glands. J Mol Med 2006; 84:75-87. https://doi.org/10.1007/s00109-005-0715-8

30 Wan M, Tang X, Stsiapanava A, Haeggström JZ. Biosynthesis of leukotriene B4. Semin Immunol 2017; 33:3-15. https://doi.org/10.1016/j.smim.2017.07.012

31 D'Almeida RE, Isla MI, De L. Vildoza E, Quispe C, SchmedaHirschmann G, Alberto MR. Inhibition of arachidonic acid metabolism by the Andean crude drug Parastrephia lucida (Meyen) Cabrera. J Ethnopharmacol 2013; 150:1080-1086. https://doi.org/10.1016/j.jep.2013.10.014 
32 Pirasut Rodanant. Cytotoxic and anti-inflammatory activity of some Thai medicinal plants. J Med Plants Res 2012; 6:40634068. https://doi.org/10.5897/JMPR12.644

33 Song X, Xia Y-X, He Z-D, Zhang H-J. A Review of Natural Products with Anti-Biofilm Activity. Curr Org Chem 2017; 22:789-817. https://doi.org/10.2174/1385272821666170620110041

34 Sandasi M, Leonard CM, Van Vuuren SF, Viljoen AM. Peppermint (Mentha piperita) inhibits microbial biofilms in vitro. South African J Bot 2011; 77:80-85.

https://doi.org/10.1016/j.sajb.2010.05.011

35 Vu B, Chen M, Crawford RJ, Ivanova EP. Bacterial extracellular polysaccharides involved in biofilm formation. Molecules 2009; 14:2535-2554. https://doi.org/10.3390/molecules14072535

36 Ouedraogo V, Kiendrebeogo M. Methanol Extract from Anogeissus leiocarpus (DC) Guill. et Perr. (Combretaceae) Stem
Bark Quenches the Quorum Sensing of Pseudomonas aeruginosa PA01. Medicines 2016; 3:26. https://doi.org/10.3390/medicines3040026

37 Choi O, Kang DW, Cho S, Lee Y, Kang B, Bae J et al. Anti-quorum sensing and anti-biofilm formation activities of plant extracts from South Korea. Asian Pac J Trop Biomed 2018; 8:411-417. https://doi.org/10.4103/2221-1691.239429

38 Oh DH, Chen X, Daliri EBM, Kim N, Kim JR, Yoo D. Microbial etiology and prevention of dental caries: Exploiting natural products to inhibit cariogenic biofilms. Pathogens 2020; 9:1-15. https://doi.org/10.3390/pathogens9070569

39 Høiby N, Bjarnsholt T, Givskov M, Molin S, Ciofu O. Antibiotic resistance of bacterial biofilms. Int J Antimicrob Agents 2010; 35:322-332. https://doi.org/10.1016/j.ijantimicag.2009.12.011 